\title{
Structural Analysis of Dairy Cattle Barns in Ilgin and Their Effects on Environmental Pollution
}

\author{
Ejder Demir and Selda Uzal Seyfi
}

\begin{abstract}
Global warming is one of the most important environmental problems. Gases originating from dairy farms have an important place in world greenhouse gas production. In order to minimize the environmental impact of harmful gases originating from milk production, dairy cattle barns must be constructed in accordance with the planning principles. In addition, it is possible to increase the quantity and quality of the milk, which has an indispensable place in human nutrition, as the barns are constructed in accordance with the animal welfare as well as the limit level of the harmful gas in the barn. This can be done in two steps. First, it is necessary to investigate the suitability of existing livestock building for animal breeding and to propose solutions by identifying problems. In the second stage, the newly established livestock buildings are designed which is appropriate for animal welfare. This study was carried out in 2017-2018 in order to examine the structural characteristics of dairy cattle barns in the Ilgin district of Konya in Turkey and to determine its suitability for animal welfare and the effects on the environment. In the study, 20 shelters with the ability to represent dairy cattle houses in the region were investigated. The shelters examined in the study were determined by purposeful sampling method. In the study, face-to-face surveys were conducted to determine the characteristics of dairy farms and barns. Measurement, observation and photographing were carried out in order to examine the structural features of the shelters in more detail. As a result of the study, it was determined that about $50 \%$ of the dairy cattle barns were built in the last ten years and $25 \%$ were built before 1990 . it was determined that while the owners of the shelters designed the shelter projects with his own thought in $70 \%$ of the shelters surveyed, they designed projects with support of an expert in only $30 \%$. In the majority of the farms surveyed, no measures against environmental pollution were observed. The elimination of the deficiencies of the shelters in the research area will be very useful in terms of animal welfare, production performance and environmental pollution.
\end{abstract}

Index Terms-Dairy cattle houses, dairy farms, structural analysis, environmental pollution, Konya.

\section{INTRODUCTION}

The most negative effect of animal production on the environment is the source of a number of infectious disease agents. The propagation ways of these factors on the environment are direct pulses and indirect pulses. The pits where are stored wastes which are removed from barns and poultry poses create a great danger as a source of disease for humans and animals.

It is seen that some disease agents originating from animals

Manuscript received April 27, 2018; revised July 21, 2018.

The authors are with Selcuk University, Faculty of Agriculture, Dept. of Farm Structure and Irrigation, Konya, Turkey (e-mail: edemir@gmail.com, seldauzal@selcuk.edu.tr). can survive for about 1 week to 3 years in nature and that pollution to be formed in the environment has not lost its activity for a very long time and continues its life as a microorganism [1].

Inside of the shelter is created temperature, humidity, air flow and various gases, odors and dusts, slaughtering products arising from cutting and processing applied to dead animals constitute the external environment.

Other auxiliary structures which outside of shelter in court of the dairy farm (slaughterhouse, fertilizer, feed depot, etc.) have been created an agricultural operation together with animal shelter, environmental pollution arises as a result of the operations applied in these areas. For this reason, it is necessary to remove the harmful wastes that cause environmental pollution, which adversely affect human and animal health, both within and outside the agricultural structure. If this is not possible, it should be kept below the tolerance values which will not harm the environment [2], [3].

Livestock produces a large of amount of fertilizer depending on the capacity of the dairy farms. Fertilizer operation is one of the main problems in many businesses and there is not much emphasis on processes such as cleaning, removing, storing and applying fertilizer. Solid and liquid fertilizers in barns are collected or thrown in an unplanned way. Exception of the Black Sea region of Turkey's territory $65 \%$ organic deficiency is known [4]. When we consider the lack of organic matter of $65 \%$ in our soil, the evaluation of organic fertilization in this way causes the national wealth to be wasted and great environmental problems. Farming has been developed in the countries, has been recorded a lot of progresses at the point of fertilizer operation and management in the countries [5].

During history, animal raising has played an important role in the social and economic achievement of societies. Livestock has been a branch of agricultural activities; the population has been interested in farming deal with both livestock and land while obtaining various products.

As the culture level of the societies increased, there has been also an improvement in livestock breeding, and it has been recorded an increase in animal products from various species. Livestock has contributed to the economies of all countries at varying rates. Although Türkiye has an important place in terms of the numbers of animal, the production of animal products is low. Animal breeding in Türkiye holds an important place in terms of being in feeding the growing population and industrial raw materials. Although animal breeding has developed rapidly in our country, it has not reached the desired level. Türkiye has a great potential in terms of livestock with a variety of climates and pastures. Animal breeding is an indispensable sector in economic and 
social terms due to the activities it has created in agriculture [6], [7].

Animal houses provides suitable and stress-free areas for viable and so this is one of the most important factors affecting the productivity of animals and an economic operation. This is possible to create stress-free shelter areas according to the preferences of animals [8] (Uğurlu and Uzal 2002).

Yağanoğlu [9] reported that minimizing the effects of environmental conditions on animals and keeping them at economic boundaries would only be possible by developing appropriate solution proposals by investigating existing shelters in different climatic and environmental conditions.

There are 15.943.537 total cattle in turkey in 2017 [4]. The cattle in Konya is $890,545,345$ [4]. Konya is ranked first in terms of number of cattle in Turkey. At the same time it is ranked first in terms of 1,200,055 (tons) milk production in Turkey (nearly 18.8 million tons) [4]. Konya - Ilgin has an important share about 41,000 bovine animals among Konya Districts. It is taken parted in research because of these potentials.

Global warming is one of the most important environmental problems. Gases originating from dairy farms have an important place in world greenhouse gas production. In order to minimize the environmental impact of harmful gases originating from milk production, dairy cattle barns must be constructed in accordance with the planning principles. In addition, it is possible to increase the quantity and quality of the milk, which has an indispensable place in human nutrition, as the barns are constructed in accordance with the animal welfare, as well as the limit level of the harmful gas in the barn. This can be done in two steps. First, it is necessary to investigate the suitability of existing livestock building for animal breeding and to propose solutions by identifying problems. In the second stage, the newly established livestock buildings are designed which is appropriate for animal welfare.

The aim of this study was to determine the structural properties of dairy cattle barns and the effects of them on environmental pollution in the Konya, ranks first in milk production in Turkey, Ilgin that has a significant potential. In this study, the structural properties of dairy cattle barns, appropriateness of animal breeding and animal welfare, the effects of dairy cattle breeding on environmental pollution were investigated and the solution proposal was tried to be developed.

\section{MATERIAL AND METHODS}

This study was carried out in 2017-2018 in order to examine the structural characteristics of dairy cattle barns in the Ilgin district of Konya in Turkey and to determine its suitability for animal welfare and the effects on the environment. In the study, 20 shelters with the ability to represent dairy cattle houses in the region were investigated. The shelters examined in the study were determined by purposeful sampling method. In the study, face-to-face surveys were conducted to determine the characteristics of dairy farms and barns. Measurement, observation and photographing were carried out in order to examine the structural features of the shelters in more detail.

The important part of investigated dairy farms consists of livestock buildings with loose and freestall barn planning system. In the selected dairy farms, a questionnaire including a structural properties of the dairy farms, land use, labor force utilization, level of technology usage, where the shelter project was procured, transportation conditions and problems, manure management and requirements were prepared and a survey study was conducted.

The suitability of examined the dairy cattle barns in the study in accordance with the planning principles, animal behavior and welfare and their effects on environmental pollution was evaluated by using the studies of Olgun [10], Uzal Seyfi [11], [12], Uzal [13], Ekmekyapar [14], Blowey [15], Webster [16] and Balaban and Şen [17].

\section{RESULTS AND DISCUSSION}

\section{A. General Characteristics of the Dairy Farms}

The distribution of the investigated dairy farms in this study according to their location is determined according to the density of the dairy cattle farms in the research area and given in Table 1. Distribution of the dairy farms according to their positions is as follows; Ilgın center $20 \%$, Ağlar neighborhood $20 \%$, Zaferiye neighborhood $10 \%$, Uçarı neighborhood $10 \%$, Gedikören neighborhood $15 \%$ and Orhaniye neighborhood $25 \%$ (Table I).

TABLE I: THE DISTRIBUTION OF THE INVESTIGATED DAIRY FARMS IN THIS STUDY ACCORDING TO THEIR LOCATION

\begin{tabular}{lll}
\hline \hline Location of Dairy Farms & $\begin{array}{l}\text { Number of Dairy } \\
\text { Farms }\end{array}$ & Percentage, \% \\
\hline Ilgın(centre) & 4 & 20 \\
Orhaniye & 5 & 25 \\
Ağlar & 4 & 20 \\
Zaferiye & 2 & 10 \\
Uçarı & 2 & 10 \\
Gedikören & 3 & 15 \\
Total & 20 & 100 \\
\hline
\end{tabular}

It is found that $70 \%$ of the investigated dairy farms have loose housings, $15 \%$ were freestall system and $15 \%$ were farmed in tie-stall shelters. The fact that a significant portion of the dairy farms $(85 \%)$ are planned in loose housing and free-stall housing systems that is more appropriate for animal welfare is a positive development in terms of increasing animal production and eliminating the adverse effects of environmental conditions on livings. Öztürk [18] reported that $92 \%$ of the shelter systems used in the dairy farms were loose housing systems and $8 \%$ were freestall housing systems. Uğurlu and Uzal [19] emphasize the appropriateness of loose and freestall houses to ensure that animals are housed in environments that are close to their natural surroundings and that animals benefit more from fresh air and sunlight to reduce the stress effect on animals.

The average capacity of the investigated dairy farm with tie-stall houses in the study is 20 heads and above while it is over 70 heads in the dairy farm with loose and freestall houses. In this study, only the characteristics of loose and freestall houses have been examined since it is a more suitable 
planning system for animal welfare.

\section{B. The Structure Properties of Dairy Cattle Barns}

In this study, when the investigated dairy cattle barns are evaluated according to their animal capacities; $20-40$ heads of $30 \%$ of dairy farms, $41-60$ heads of $20 \%, 61-80$ heads of $20 \%$, $81-100$ heads of $15 \%$ and 101 heads and over. Nearly $70 \%$ of the examined dairy farm in this study are over 60 heads.

TABLE II: DISTRIBUTION OF THE INVESTIGATED DAIRY BARNS ACCORDING TO ANIMAL CAPACITIES

\begin{tabular}{lll}
\hline \hline Number of animals & Number of dairy barns & Percentage, $\%$ \\
\hline $20-40$ & 6 & 30 \\
$41-60$ & 4 & 20 \\
$61-80$ & 4 & 20 \\
$81-100$ & 3 & 15 \\
101 and above & 3 & 15 \\
Total & 20 & 100 \\
\hline
\end{tabular}

In the study, the examined dairy cattle barns are evaluated in 6 groups according to their establishment dates. It is as follows; shelters prior to foundation year 1990 1st group, 1990-1995 2nd group, 1996-2000 3rd group, 2001-2005 dates 4th group, 2006-2010 dates 5th group, shelters after 2010 6th group (Table III). It has been determined that $60 \%$ of the examined shelters in the study were established after 2000. It has been determined that $25 \%$ of the shelters are before 1990 year of establishment. Nearly $50 \%$ of the shelters are found to have been established within the last 10 years.

TABLE III: DisTRIBUTION OF THE INVESTIGATED DAIRY CATTLE BARNS ACCORDING TO FOUNDATION YEAR

\begin{tabular}{lll}
\hline \hline The group of barns & Foundation years & Percentage, $\%$ \\
\hline $1^{\text {st }}$ group & $<1990$ & 25 \\
$2^{\text {nd }}$ group & $1990-1995$ & 5 \\
$3^{\text {rd }}$ group & $1996-2000$ & 10 \\
$4^{\text {th }}$ group & $2001-2005$ & 10 \\
$5^{\text {th }}$ group & $2006-2010$ & 20 \\
$6^{\text {th }}$ group & $2010<$ & 30 \\
Total & 20 & 100 \\
\hline
\end{tabular}

It has been determined that $70 \%$ of the shelters surveyed in the study have built their own sheltered and inspired shelters and $30 \%$ have received technical support and assistance from private firms. In the purchase of technical support, it was determined that the standard projects prepared by the companies to which the milking unit was awarded were used. Kayar [20] found that $42.4 \%$ of the livestock houses owners had made inspections in the sample dairy farm before the start of the construction of the shelter and that they got information from the owners, $33.3 \%$ of them had done the shelter and auxiliary facilities with their own experiences, $6 \% 1$ of them visited and used their own farms, $3 \%$ of them benefited from the projects in the Provincial Directorate of Agriculture and $3 \%$ of them stated that they had made shelter and auxiliary facilities by consulting with technical staff.

Material Types and Dimensions of Building Elements of Dairy Cattle Barns

The floor areas required for animals has a very important place in terms of animal welfare and production performance. The stocking density of the resting areas are calculated as $3.51-3.80 \mathrm{~m}^{2}$ per animal in $15 \%$ of the examined dairy cattle barns, 5.01-6.50 $\mathrm{m}^{2}$ per animal in 20\%, and higher than 6.50 $\mathrm{m}^{2}$ per animal in $50 \%$ of them (Table IV). Olgun [10] and Ekmekyapar [14] reported that it would be more appropriate to plan the stocking density of the resting area as $5-7 \mathrm{~m}^{2}$ per animal, and Uzal [13] reported as $6-10 \mathrm{~m}^{2}$ per animal for resting area in terms of animal welfare and increasing animal production. In this study, approximately $50 \%$ of the examined shelters were appropriately planned for the literature reports.

TABLE IV: DISTRIBUTION OF THE INVESTIGATED DAIRY CATTLE BARNS ACCORDING TO STOCKING DENSITY OF RESTING AREA

\begin{tabular}{lll}
\hline \hline $\begin{array}{l}\text { The stocking density of resting } \\
\text { area }\end{array}$ & $\begin{array}{l}\text { Number of dairy } \\
\text { barns }\end{array}$ & Percentage, \% \\
\hline$<3.5 \mathrm{~m}^{2}$ per animal & 0 & 0 \\
$3.51-3.80 \mathrm{~m}^{2}$ per animal & 3 & 15 \\
$3.81-5.00 \mathrm{~m}^{2}$ per animal & 3 & 15 \\
$5.01-6.50 \mathrm{~m}^{2}$ per animal & 4 & 20 \\
$6.50 \mathrm{~m}^{2}$ per animal & 10 & 50 \\
Total & 20 & 100
\end{tabular}

In this study, the stocking density of courtyard areas is calculated as $4.80-6.90 \mathrm{~m}^{2}$ per animal in $15 \%$ of the shelters, $7.00-8.90 \mathrm{~m}^{2}$ per animal in $35 \%$ and the higher than $9.00 \mathrm{~m}^{2}$ per animal in 50\% of the shelters (Table V). Olgun [10] and Ekmekyapar [14] were reported that it would be more appropriate to plan the stocking density of the courtyard area should be at least as much as the resting area. Preferably, however, it is more convenient to leave an area twice as large. The courtyard stocking density should be separated for soil-based courtyard areas as $30 \mathrm{~m}^{2}$ per animal for dairy cows and $20 \mathrm{~m}^{2}$ per animal for young cattle [10]. In terms of animal welfare, it is more appropriate to leave the courtyard area as a soft natural ground and $15-25 \mathrm{~m}^{2}$ per animal [13]. Increasing the courtyard area per animal in a significant portion of the examined barns would be beneficial in increasing animal production.

TABLE V: DISTRIBUTION OF THE INVESTIGATED DAIRY CATTLE BARNS ACCORDING TO STOCKING DENSITY OF COURTYARD AREA

\begin{tabular}{lll}
\hline \hline The stocking density of courtyard area & $\begin{array}{l}\text { Number of dairy } \\
\text { barns }\end{array}$ & $\begin{array}{l}\text { Percentage, } \\
\%\end{array}$ \\
\hline$<4.00 \mathrm{~m}^{2}$ per animal & 0 & 0 \\
$4.00-4.90 \mathrm{~m}^{2}$ per animal & 1 & 5 \\
$5.00-6.90 \mathrm{~m}^{2}$ per animal & 2 & 10 \\
$7.00-8.90 \mathrm{~m}^{2}$ per animal & 7 & 35 \\
$9.00 \mathrm{~m}^{2}$ per animal $<$ & 10 & 50 \\
Total & 20 & 100 \\
\hline
\end{tabular}

The floor, walls and foundations of dairy cattle barns have a significant share in stability. The resting areas of the examined shelters; $10-20 \%$ of the shelters have a height of $11-20 \mathrm{~cm}, 15 \%$ of them are $21-30 \mathrm{~cm}$ and $25 \%$ of them are $31-40 \mathrm{~cm}$ higher than the ground of courtyard area. However, in the $50 \%$ of the shelters, the resting area is at the same level with the ground of courtyard area. It has been determined that the floor of resting area is constructed as concrete in the whole of the loose houses. The floor of courtyard areas is constructed as cobblestone in $60 \%$ of them while compacted soil in $20 \%$ of them.

The basic width of the studied shelters is $40-60 \mathrm{~cm}$ and the basic depths are around $80-150 \mathrm{~cm}$. Okuroğlu and Delibaş [21] suggest that the depth of the base frosts in cold regions should 
be $80-130 \mathrm{~cm}$. This shows that the existing bases are at a sufficient depth.

The shelter walls were made of mud brick at $5 \%$ of the barn, brick at $50 \%$ of them and brick at $45 \%$ of them. No stonewall was found in any of the dairy cattle barns. In only $10 \%$ of the shelters, the shelter is made of briquettes and bricks made of concrete or stonewall with a height of about $50-100 \mathrm{~cm}$ from the wall.

In the studied houses, $25 \%$ wood and $75 \%$ steel constructions were used as roof frame. $60 \%$ of the examined shelters were built as cradle roofs and $40 \%$ were constructed as porch roofs. As roofing material, $15 \%$ of shelters are eternit (eternit on $5 \mathrm{~cm}$ thick board), $15 \%$ are tile $(10 \mathrm{~cm}$ reed coat, 5 $\mathrm{cm}$ mud straw mixture, tile on), $65 \%$ insulation and roofing were not used) and $5 \%$ had sandwich panels. $65 \%$ of the shelters examined did not use insulating material.

Door widths are less than $90 \mathrm{~cm}$ in $20 \%, 90-120 \mathrm{~cm}$ in $20 \%$, and $120 \mathrm{~cm}$ in $70 \%$ in $10 \%$ of the shelters where the research is carried out. The door heights of the loose houses were measured $195 \mathrm{~cm}$ above the shelters. $20 \%$ of the shelter doors are made of wood and $80 \%$ of the barns are made of niobium steel. It is recommended that the width of the door is $120 \mathrm{~cm}$ and the height of the door is $200 \mathrm{~cm}$, where the animals can freely enter and exit the barriers where the existing material and feed entrance are by hand [14]. It can be said that the door sizes of almost all of the examined loose houses are sufficient.

The window of investigated dairy cattle barn are wood in $25 \%$ of the shelters, and $75 \%$ of them preferred iron windows. Of the barn windows, $45 \%$ are $51-100 \mathrm{~cm}$ and $55 \%$ are $101-150 \mathrm{~cm}$. The height of the windows, $55 \%$ is $31-90 \mathrm{~cm}$, $45 \%$ is $91-120 \mathrm{~cm}$. In the examined shelters, the elevation from the shelter floor of the windows was found to be 95-150 $\mathrm{cm}$ in $40 \%$ of the shelters and around $150-190 \mathrm{~cm}$ in $60 \%$ of the shelters. Balaban and Sen [17] suggest that the window width and height should be $100 \mathrm{~cm}$ or more in a shelter with 20 heads in order to enlighten the shelter and to ensure good visibility.

Uğurlu and Uzal [19] report that animals should be housed in environments that are close to their natural environment in order to reduce the stress effect on the animals and emphasize that the breadth of the open area must be as large as possible for animals to benefit more from fresh air and sunlight and is observed an improvement in this area. The dairy farms should follow the technology and account the animal population and the shelters should be designed according to these data.

\section{CONCLUSION}

As a result of the study, it was determined that about $50 \%$ of the dairy cattle barns were built in the last ten years and $25 \%$ were built before 1990 . it was determined that while the owners of the shelters designed the shelter projects with his own thought in $70 \%$ of the shelters surveyed, they designed projects with support of an expert in only $30 \%$. In the majority of the farms surveyed, no measures against environmental pollution were observed. The elimination of the deficiencies of the shelters in the research area will be very useful in terms of animal welfare, production performance and environmental pollution.

\section{REFERENCES}

[1] M. Ergül, "Hayvansal Üretim ve Çevre Kirliliği," Yem Sanayi Dergisi, Ankara. 1989.

[2] M. Okuroğlu, "Hayvan Barınaklarında Zararlı Gazlar, Toz ve Etkileri," Et ve Balık Endüstrisi Dergisi, vol. 8, no. 49, pp. 19-24, 1987.

[3] T. Alagöz, Y. Kumova, A. Atılgan, and A. Akyüz, "Hayvanc1lı Tesislerinde Ortaya Çıkan Zararlı Atıklar ve Yarattığı Çevre Kirliliği Üzerine Bir Araştırma," Tarım-Çevre İlişkileri Sempozyumu, Mersin Üniversitesi Mühendislik Fakültesi Yayınları, 1996.

[4] Anonim. (2017). [Online]. Available: www.tu1k.gov.tr

[5] E. Şimşek, E. Yaslıŏglu, and İ. Arıcı, "Süt Sığırcılığı İşletmelerinde Gübre Yönetimi ve Gübre işletim Sistemlerinin Planlanması. GAP II," Tarım Kongresi, vol. 2, pp. 715-722, Şanlıurfa, 2001

[6] Anonymous. (2009). Anadolu Üniversitesi Yayınları, Açık öğretim Fakültesi Yayınları. [Online]. Available: http://books.google.com/books

[7] M. Çayır, "Büyükbaş Hayvan Barınaklarında Oluşan Atıkların Çevre Üzerine Etkileri, Yüksek Lisans Tezi, Süleyman Demirel Üniversitesi," Fen Bilimleri Enstitüsü Tarımsal Yapılar ve Sulama Anabilim Dalı, 2010.

[8] N. Uğurlu and S. Uzal, "Konya ilinde süt sığırları için serbest duraklı barınak tasarımında alternatif yaklaşım," S. U. Ziraat Fakültesi Dergisi, vol. 16, no. 30, pp. 49-55, 2002.

[9] V. A. Yağanoğlu, "Kümeslerde Zararlı Gazlar Koku ve Toz Oluşumu Zararları ve Etkilerinin Giderilme Yolları," Teknik Tavukçuluk Dergisi, vol. 58, pp. 8-15, 1987.

[10] M. Olgun, Tarımsal Yapılar, Anakara Üniversitesi Yayınları No: 244," Ankara Üniversitesi Basımevi, Ankara, 2016.

[11] S. U. Seyfi, "Hourly and seasonal variations in the area preferences of dairy cows in freestall housing," J. Dairy Sci., vol. 96, pp. 906-917, 2013.

[12] S. U. Seyfi, "Seasonal variation of the lying and standing behavior indexes of dairy cattle at different daily time periods in free-stall housing," Animal Science Journal, vol. 84, pp. 708-717, 2013.

[13] S. Uzal, "Serbest ve serbest duraklı süt sığırı barınaklarında hayvanların alan kullanımı ve zaman bütçesine mevsimlerin etkisi," $\mathrm{PhD}$ thesis, Entitute of Natural and Applied Sciences, Department of Farm Structure and Irrigation, Selçuk University, Konya, Turkey, 2008.

[14] T. Ekmekyapar, "Tarımsal Yapılar. Atatürk Üniversitesi Ziraat Fakültesi Yayınları No: 204," Erzurum, 2001.

[15] R. Blowey, "Dairy cow housing," Livestock Housing, Cambridge University Press, Cambridge, pp. 305-337, 1994.

[16] A. J. F. Webster, "Comfort and injury," Livestock Housing, University Press, Cambridge, pp. 49-67, 1994

[17] A. Balaban and E. Şen, "Tarımsal Yapılar. Ankara Üniversitesi Ziraat Fakültesi Yayınları, Ders Kitabı No.845,” Ankara, 1988.

[18] İ. Öztürk, "İzmir-Tire Yöresi Süt Sığırcıllı̆ı İşletmelerinde Gübre Yönetim Sistemleri Ve Geliştirilme Olanakları, Yüksek lisans tezi," Ege Üniversitesi Fen Bilimleri Enstitüsü, İzmir, 2009.

[19] N. Uğurlu and S. Uzal, "Süt Sı ğırı barınaklarının tasarımında mevsimsel etkiler," Selçuk Üniversitesi Ziraat Fakültesi Dergisi, vol. 18, no. 33, pp. 73-79, 2004.

[20] Y. Kayar, "Denizli Yöresi Süt Sığırcılığı İsletmelerinde Barınakların Yapısal Yönden Değerlendirilmesi, Yüksek lisans tezi," Adnan Menderes Üniversitesi Fen Bilimleri Enstitüsü, Denizli, 2011.

[21] M. Okuroğlu and L. Delibaş, "Hayvan Barınaklarında Yapı Elemanlarının Projelendirme İlkeleri," Teknik Tavukçuluk Dergisi, vol. 55, pp. 3-13, Ankara, 1987.

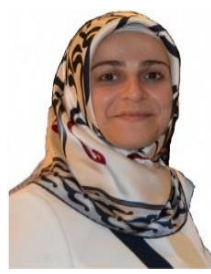

Selda Uzal Seyfi was born in Samsun, Turkey in 1980. He received the B.Sc. degree in Dept. of Farm Structures and Irrigation from Ondokuz May1s University and the M.Sc. and Ph.D. degree in Dept. of Farm Structures and Irrigation from Selcuk University in Turkey in 2001, 2004, and 2008, respectively.

From 2001 to 2014, she had been a research assistant at Dept. of Farm Structures and Irrigation, Selçuk University, Konya, Turkey. She has been Assoc. Prof. Dr. since 2014 at the same department. Her research interests include animal behaviour, farm structures and dairy farms. 